\title{
MALABSORPTION IN JOHNE'S DISEASE IN CATTLE: AN IN-VITRO STUDY OF L-HISTIDINE UPTAKE BY ISOLATED INTESTINAL TISSUE PREPARATIONS
}

\author{
D. S. P. Patterson AND Sylvia BerRett \\ Central Veterinary Laboratory, Weybridge
}

\section{Plate XXVI}

CATTLE naturally infected with Mycobacterium johnei slowly develop a clinical disease characterised by chronic diarrhoea and severe muscular wasting. At necropsy, the wall of the small intestine is enlarged and microscopically there appears to be some thickening of the mucosa accompanied by abundant accumulations of epithelioid cells in the submucosa (Jubb and Kennedy, 1963). It is uncertain whether the extent of the intestinal lesions can be correlated with the severity of the clinical condition.

Altered gut permeability to plasma proteins has recently been demonstrated, as shown by increased leakage rates for albumin (Nielsen, 1966) and $\beta$-globulins (Patterson, Allen and Lloyd, 1967). In addition, there is increased gut motility and a decreased intestinal transit time in the diarrhoea of clinical Johne's disease (Patterson, Allen and Lloyd, unpublished observations). These factors, coupled with possible amino-acid malabsorption, could account for the development of the typical wasted condition of clinical cases.

The present report provides evidence for amino-acid malabsorption from an in-vitro study of histidine uptake by intestinal tissue preparations obtained at necropsy from healthy and affected cows. A preliminary account of this work has already been published (Patterson and Berrett, 1968).

\section{MATERIALS AND METHODS}

Animals. Ten carefully diagnosed cases of clinical Johne's disease, two known subclinically infected cows and nine healthy controls were used in this study. All the animals were in approximately the same absorptive state at the time when they were killed by intravenous injection of pentobarbital. They were last fed in the evening, and killed early on the following morning. Intestinal tissue was always obtained within a few minutes of death.

Intestinal tissue preparations. Because the tissues had to be processed quickly, no attempt was made to select particularly severely affected areas of the gut from clinical or subclinical cases of Johne's disease. To obtain valid comparisons with normal tissues a standard sampling procedure was adopted in which a piece of ileum was always taken approximately $12 \mathrm{in}$. $(30 \mathrm{~cm})$ proximal to the ileocaecal valve. This is the region of the intestine commonly infected with Myco. johnei. Fat and mesenteric connexions were dissected away from the excised length of ileum, and it was rinsed free from its contents with warm saline at $37^{\circ} \mathrm{C}$. Rings of whole ileum were prepared immediately, as described below, and then transported to the laboratory in warm oxygenated Krebs-Ringer bicarbonate solution in a Dewar flask. Mucosal scrapings were kept on ice.

Received 28 Aug. 1968; accepted 7 Jan. 1969.

J. MED. MICROBIOL.-VOL. 2 (1969) 
In the first experiment, rings of ileum (Agar, Hird and Sidhu, 1954) were prepared by cutting across the length of the washed segment of intestine with a scalpel at intervals of about $5 \mathrm{~mm}$. The rings so prepared were immediately placed in oxygenated Krebs-Ringer bicarbonate at $37^{\circ} \mathrm{C}$. The photographs in fig. 1 show ring preparations from a healthy and a diseased cow. Thickening of the intestinal wall was always apparent in the latter group. The rings were everted, mucosal surface outside, as shown in fig. 1, before incubation in Krebs-Ringer bicarbonate solution.

The preparation used in the second experiment consisted of ileum mucosal scrapings. These were made by first slitting open the length of washed ileum to form a flat sheet and then scraping off the mucosa with the edge of a blunt instrument (spatula or microscope slide) by gentle pressure. Fig. 2 shows a low-power photomicrograph of a section of such a preparation in which the mucosa appears to have been stripped off at the muscularis mucosae.

Measurement of histidine uptake in vitro. The procedure was essentially that of Agar et al. for both experiments: the total accumulation of free histidine was measured after incubation in Krebs-Ringer bicarbonate at $p \mathrm{H} 7.4$ containing 0.5 per cent. glucose and $20 \mathrm{~mm}-\mathrm{L}$-histidine under an atmosphere of oxygen:carbon dioxide $(95 \mathrm{v} / \mathrm{v})$. Three or four rings of ileum weighing about $20 \mathrm{~g}$ were incubated in $200 \mathrm{ml}$ medium and in the case of mucosal scrapings (about $100 \mathrm{mg}$ tissue) $3 \mathrm{ml}$ medium was used. After 60 minutes' incubation, the tissue preparations were washed in saline, blotted dry and homogenised in a suitable volume of water.

Trichloroacetic acid extracts of incubated tissues, prepared after homogenisation, were analysed for free histidine by the sensitive colorimetric method of MacPherson (1946). Allowance was made for the free histidine content of tissues that had been incubated in the absence of this amino acid, under conditions in which no detectable leakage of histidine occurred. In agreement with the views of Newey and Smyth (1967) it was found to be more accurate to assess amino-acid uptake by this direct method rather than attempt to measure the small differences produced in the medium histidine concentration (cf. Agar et al.).

The proportion of "active" amino-acid uptake was assessed by observing the inhibition of histidine uptake when $0 \cdot 2 \mathrm{~mm}$-2:4-dinitrophenol (DNP) was added to the incubation medium.

Substantially no further uptake of histidine occurred in either preparation of bovine ileum tissues after 60 minutes' incubation at $37^{\circ} \mathrm{C}$.

\section{RESULTS}

\section{Length and thickness of the small intestine}

The length of small intestine from the rumen to the ileocaecal valve was measured after detachment from the mesentery. In straightening it, any stretching was kept to a minimum. For 6 healthy cows the mean length was $117 \cdot 15 \pm 5 \cdot 613 \mathrm{ft}(35 \cdot 73 \pm 1 \cdot 71 \mathrm{~m})$ and for 6 clinical cases of Johne's disease the corresponding mean value was $120 \cdot 25 \pm 11.046 \mathrm{ft}(36 \cdot 68 \pm 3 \cdot 36 \mathrm{~m})$.

Weight per unit length measured in the ileum (12 in. proximal to the ileocaecal valve) was $114 \cdot 32 \pm 11.072 \mathrm{~g}$ per $\mathrm{ft}(375.07 \pm 36.03 \mathrm{~g}$ per $\mathrm{m})$ in 6 cases of clinical Johne's disease compared with a control value of $30.432 \pm 2.859 \mathrm{~g}$ per $\mathrm{ft}$ $(99 \cdot 84 \pm 9 \cdot 3 \mathrm{~g}$ per $\mathrm{m})$. This difference, which indicated a massive thickening of the intestinal wall, was statistically highly significant $(\mathrm{P}<0 \cdot 001)$.

\section{Histidine uptake by intestinal tissue preparations in vitro}

Net rates of histidine uptake by rings of ileum (expressed as $\mu$ moles taken up per $\mathrm{g}$ per $\mathrm{hr}$ at $37^{\circ} \mathrm{C}$ ) were significantly decreased in 6 clinical and 2 subclinical cases of Johne's disease compared with 6 control animals. Histidine uptake in the presence of $0.2 \mathrm{~mm}$-DNP was also significantly decreased, but the 
proportion of "active" uptake (i.e., the fraction abolished by the addition of this inhibitor to the medium) although lowered was not significantly different for the two main groups (table I). On the other hand, the absolute rate of " active" uptake was significantly lowered in the group of clinical cases.

Concentrations of free histidine in tissue water were also determined in the incubated rings of ileum tissue and a lower mean concentration of free histidine $(8.39 \pm 0.68 \mu$ moles per $g$ tissue water) was reached in ileum tissue from 6 cases of Johne's disease after 60 minutes' incubation, compared with $17 \cdot 49 \pm 2.03$ $\mu$ moles per $\mathrm{g}$ for 6 healthy cows.

TABLE I

Histidine uptake in vitro by rings of whole ileum from healthy cows and cases of Johne's disease

\begin{tabular}{|c|c|c|c|c|}
\hline Group & $\begin{array}{l}\text { Description } \\
\text { of animals } \\
\text { (number) }\end{array}$ & $\begin{array}{l}\text { Net uptake of } \\
\text { L-histidine }\end{array}$ & $\begin{array}{l}\text { "Inhibited" * } \\
\text { uptake of } \\
\text { L-histidine }\end{array}$ & $\begin{array}{l}\text { “ Active" uptake } \\
\text { of L-histidine } \\
\text { (per cent.) }\end{array}$ \\
\hline 1 & $\begin{array}{l}\text { Healthy } \\
\text { controls (6) }\end{array}$ & $13 \cdot 18 \pm 1 \cdot 68$ & $7 \cdot 20 \pm 0 \cdot 70$ & $43 \cdot 55 \pm 4 \cdot 08$ \\
\hline 2 & $\begin{array}{l}\text { Clinical } \\
\text { Johne's } \\
\text { disease (6) }\end{array}$ & $6 \cdot 18 \pm 0 \cdot 60$ & $3 \cdot 97 \pm 0 \cdot 44$ & $35 \cdot 67 \pm 5 \cdot 46$ \\
\hline 3 & $\begin{array}{l}\text { Subclinical } \\
\text { Johne's } \\
\text { disease }\end{array}$ & $\begin{array}{r}8 \cdot 07 \\
11.34\end{array}$ & $\begin{array}{l}5 \cdot 84 \\
5 \cdot 82\end{array}$ & $\begin{array}{l}27 \cdot 6 \\
47 \cdot 5\end{array}$ \\
\hline \multicolumn{2}{|c|}{$\begin{array}{l}\text { Statistical significance } \\
\text { of the difference be- } \\
\text { tween groups } 1 \text { and } 2\end{array}$} & $\mathbf{P}<0.01$ & $\mathbf{P}<0.01$ & Not significant \\
\hline
\end{tabular}

Rates expressed as $\mu$ moles L-histidine taken up per $\mathrm{g}$ fresh wt per $\mathrm{hr}$ at $37^{\circ} \mathrm{C}$ (mean values $\pm \mathrm{SE}$ where appropriate).

* Uptake of histidine measured in the presence of 0.2mm-DNP.

Data presented in table II show that the net histidine uptake per $g$ of fresh mucosal tissue per hr was significantly reduced in Johne's disease. There was no significant difference between the two main groups in the rates of histidine accumulation in the presence of the inhibitor DNP, showing that it was "active" transport that was affected. The proportion of "active" uptake was reduced from a mean value of 61.05 per cent. for control tissue to 25.27 per cent. for tissue from cases of Johne's disease.

Uptake of histidine expressed as the rates of increase in the concentration of this free amino acid in mucosal tissue water was markedly different in the two main groups (table III). The mean concentration of free histidine ultimately reached in the control group was almost $34.0 \mathrm{~mm}$ or about 1.7 times the concentration in the ineubation medium. In contrast with the results for rings of ileum (expt I), it was found that each of the 6 normal mucosal tissue specimens accumulated free histidine to reach concentrations well in excess of 


\section{TABLE II}

Histidine uptake by isolated intestinal (ileum) mucosa obtained from healthy cows and cases of Johne's disease

\begin{tabular}{|c|c|c|c|c|}
\hline Group & $\begin{array}{l}\text { Description } \\
\text { of animals } \\
\text { (number) }\end{array}$ & $\begin{array}{l}\text { Net uptake of } \\
\text { L-histidine }\end{array}$ & $\begin{array}{l}\text { "Inhibited" } \\
\text { uptake* of } \\
\text { L-histidine }\end{array}$ & $\begin{array}{l}\text { "Active" uptake } \\
\text { of L-histidine } \\
\text { (per cent.) }\end{array}$ \\
\hline 1 & $\begin{array}{l}\text { Healthy } \\
\text { cows (6) }\end{array}$ & $26 \cdot 68 \pm 2 \cdot 72$ & $10 \cdot 47 \pm 1 \cdot 34$ & $61 \cdot 05 \pm 2 \cdot 50$ \\
\hline 2 & $\begin{array}{l}\text { Clinical } \\
\text { Johne's } \\
\text { disease (6) }\end{array}$ & $15 \cdot 33 \pm 2 \cdot 35$ & $11 \cdot 05 \pm 1 \cdot 28$ & $25 \cdot 27 \pm 6 \cdot 29$ \\
\hline 3 & $\begin{array}{l}\text { Subclinical } \\
\text { Johne's } \\
\text { disease (2) }\end{array}$ & $\begin{array}{r}18 \cdot 81 \\
7 \cdot 75\end{array}$ & $\begin{array}{r}10 \cdot 55 \\
6 \cdot 38\end{array}$ & $\begin{array}{l}43 \cdot 9 \\
17 \cdot 7\end{array}$ \\
\hline \multicolumn{2}{|c|}{$\begin{array}{l}\text { Statistical significance } \\
\text { of the difference be- } \\
\text { tween groups } 1 \text { and } 2\end{array}$} & $P<0.05$ & $\begin{array}{c}\text { Not } \\
\text { significant }\end{array}$ & $P<0.001$ \\
\hline
\end{tabular}

In-vitro rates expressed as $\mu$ moles L-histidine taken up per $\mathrm{g}$ fresh tissue per $\mathrm{hr}$ at $37^{\circ} \mathrm{C}$. (Mean values $\pm S E$ where appropriate.)

* Uptake of histidine measured in the presence of 0.2mM-DNP.

\section{TABLE III}

Accumulation of free histidine by isolated intestinal (ileum) mucosa from healthy cows and cases of Johne's disease during 60 minutes' incubation in modified Krebs-Ringer bicarbonate at $37^{\circ} \mathrm{C}$

\begin{tabular}{|c|c|c|c|c|c|}
\hline \multirow{2}{*}{ Group } & \multirow{2}{*}{$\begin{array}{l}\text { Description } \\
\text { of animals } \\
\text { (number) }\end{array}$} & \multicolumn{2}{|c|}{$\begin{array}{l}\text { Final tissue concentration of } \\
\text { L-histidine with }\end{array}$} & \multirow{2}{*}{$\begin{array}{l}\text { Net increase } \\
\quad(B-A)\end{array}$} & \multirow{2}{*}{$\begin{array}{l}\text { Increase in } \\
\text { the presence of } \\
0 \cdot 2 \mathrm{mM}-\mathrm{DNP}\end{array}$} \\
\hline & & $\begin{array}{c}\text { no histidine } \\
\text { in medium }(\mathrm{A})\end{array}$ & $\begin{array}{l}20 \text { mm-histidine } \\
\text { in medium (B) }\end{array}$ & & \\
\hline 1 & $\begin{array}{l}\text { Healthy } \\
\text { controls (6) }\end{array}$ & $1 \cdot 77 \pm 0 \cdot 21$ & $33 \cdot 95 \pm 3 \cdot 29$ & $32 \cdot 18$ 土 $3 \cdot 10$ & $12 \cdot 65 \pm 1 \cdot 62$ \\
\hline 2 & $\begin{array}{l}\text { Clinical } \\
\text { Johne's } \\
\text { disease (6) }\end{array}$ & $1 \cdot 19 \pm 0 \cdot 22$ & $19 \cdot 12 \pm 2 \cdot 79$ & $17 \cdot 93 \pm 2 \cdot 64$ & $12 \cdot 89 \pm 1 \cdot 42$ \\
\hline 3 & $\begin{array}{l}\text { Subclinical } \\
\text { Johne's } \\
\text { disease (2) }\end{array}$ & $\begin{array}{l}1 \cdot 42 \\
2 \cdot 09\end{array}$ & $\begin{array}{l}23 \cdot 97 \\
11 \cdot 31\end{array}$ & $\begin{array}{r}22 \cdot 55 \\
9 \cdot 22\end{array}$ & $\begin{array}{c}12 \cdot 6 \\
7 \cdot 72\end{array}$ \\
\hline \multicolumn{2}{|c|}{$\begin{array}{l}\text { Statistical significance } \\
\text { of the difference be- } \\
\text { tween groups } 1 \text { and } 2\end{array}$} & $\begin{array}{l}\text { Not } \\
\text { significant }\end{array}$ & $P<0.01$ & $\mathrm{P}<0.01$ & $\begin{array}{l}\text { Not } \\
\text { significant }\end{array}$ \\
\hline
\end{tabular}

Concentrations or changes in concentration expressed as $\mu$ moles L-histidine per $\mathrm{g}$ total tissue water. Mean values $\pm \mathrm{SE}$ are given where appropriate. 
the medium concentration $(20 \mathrm{~mm})$, whilst only 2 out of 7 tissues from cases of Johne's disease did so.

We calculated approximate intracellular concentrations of free histidine from the mean values in table III, using water and electrolyte distribution data obtained in another series of experiments (Patterson et al., 1968a) and assuming that the concentration of histidine in the extracellular water reached the medium concentration of $20 \mathrm{~mm}$ by a process of passive diffusion. On this basis, it appeared that histidine accumulated intracellularly up to a mean value of about $37.4 \mathrm{~mm}$ in healthy mucosa, but to only about

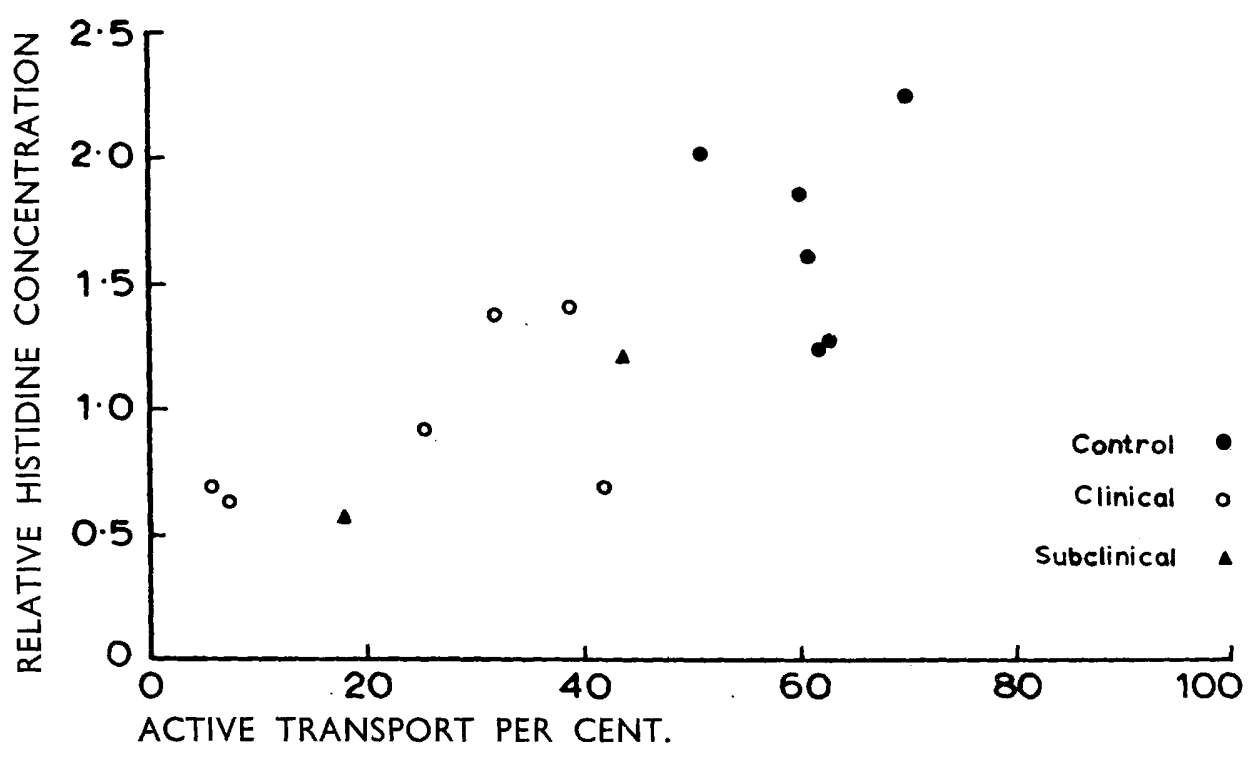

FIG. 3.-Relation between "active" uptake of histidine and the accumulation of free histidine in the mucosal layer of the ileum obtained from normal cows and from animals infected with $M y c o$ johnei. Histidine concentration expressed as ratio between concentration reached in mucosal tissue water to concentration in incubation medium after 60 minutes' incubation at $37^{\circ} \mathrm{C}$.

$19 \mathrm{~mm}$, just below the concentration of the medium, in the mucosal tissues obtained from clinical cases of Johne's disease. Values for intracellular histidine concentrations were not calculated for the individual tissue samples examined, but this calculation shows that estimates of the concentrations of free histidine in total mucosal tissue water gave a valid, if only approximate, measure of the concentrating capacity of these tissues.

When the level of free histidine reached in mucosal tissue water after 60 minutes' incubation was expressed as a fraction of the medium histidine concentration (i.e., as the ratio of tissue histidine to medium histidine concentrations) it was found that this ratio, or relative histidine concentration, was correlated with the proportion of "active" uptake occurring in the same mucosal tissue. Values for 14 cows (6 controls, 6 clinical and 2 subclinical cases) are plotted in fig. 3 , where the correlation proved to have a high degree 
of statistical significance (correlation coefficient, $\mathrm{r}=+0.776 ; \mathrm{P}<0.01$ ). This experimental relation between two parameters obtained independently indicated that the concentration of histidine reached in mucosal scrapings was dependent upon the proportion of "active" uptake occurring (i.e., on the fraction of the net uptake inhibited by $0 \cdot 2 \mathrm{~mm}$-DNP).

Since the mean rates of "inactive" uptake were almost identical in the two main groups of cows and as this proportion of the net histidine uptake was presumably due to passive diffusion, it was probable that in cases of Johne's disease diffusive entry of histidine was not impaired by a thickened mucosal layer. This was supported by microscopic observations. Sections of ileum from 12 clinical cases of Johne's disease prepared for routine purposes were stained with haematoxylin and eosin and examined with a microscope fitted with a graduated eyepiece. The mean thickness of the mucosal layer from the brush border to the muscularis mucosae $(0.847 \pm 0.041 \mathrm{~mm})$ was not significantly different from that of 9 control cows $(0.956 \pm 0.046 \mathrm{~mm})$. This result confirms the observations of Jubb and Kennedy, who attributed gross thickening of the intestine in Johne's disease to submucosal infiltration by epithelioid cells.

\section{Discussion}

Accumulation or uptake of substrates by isolated tissue in vitro has been used by several authors as a measure of the ability of intestinal tissue to absorb nutrients in vivo (Agar et al., 1954; Crane and Mandelstam, 1960; Bronk and Parsons, 1965; Huang, 1965). The rates measured are, of course, not necessarily equal to the in-vivo rates of absorption, but are still useful indices of absorption (Levin, 1967). Histidine was chosen for this study because it is apparently absorbed throughout the length of the small intestine (Wilson, 1962) and is relatively easy to estimate with accuracy at low concentrations.

When incubated under standard conditions, it was found that, for rings of whole ileum the rate of L-histidine accumulation per $\mathrm{g}$ of tissue (or tissue water) was much lower than normal in the intestinal tissues of cows affected with Johne's disease. However, a consequence of the gut thickening was to expose increased serosal surfaces to the incubation medium when ring preparations were being used. These cells although capable of histidine uptake probably do so mainly by passive diffusion and because of the relatively unaltered thickness of the mucosal layer which accompanied submucosal thickening, it appeared that "inactive" histidine uptake by these cells tended to swamp the "active" uptake by the mucosa. The result of this was that even in normal tissue the concentration of histidine in tissue water rarely exceeded the medium concentration and that in rings of diseased ileum there was only a small decrease in the proportion of "active" uptake, which was not statistically significant.

The above considerations necessitated a comparable study of isolated mucosal tissues. Mucosal scrapings were quite suitable preparations and the results obtained were unambiguous. Uptake of histidine ( $\mu$ moles per $\mathbf{g}$ fresh tissue per hr) was decreased in tissues from cases of clinical or subclinical 
L-HISTIDINE MALABSORPTION IN JOHNE'S DISEASE

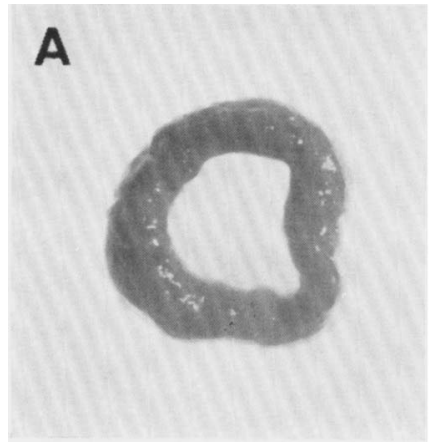

FIG. 1A.

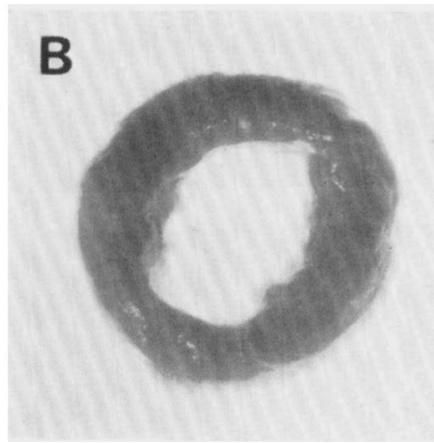

FiG. 1B.

FIG. 1.-Rings of whole ileum (A) from a normal cow, (B) from a cow suffering from clinical Johne's disease, showing gross thickening of the intestinal wall in (B). Natural size.

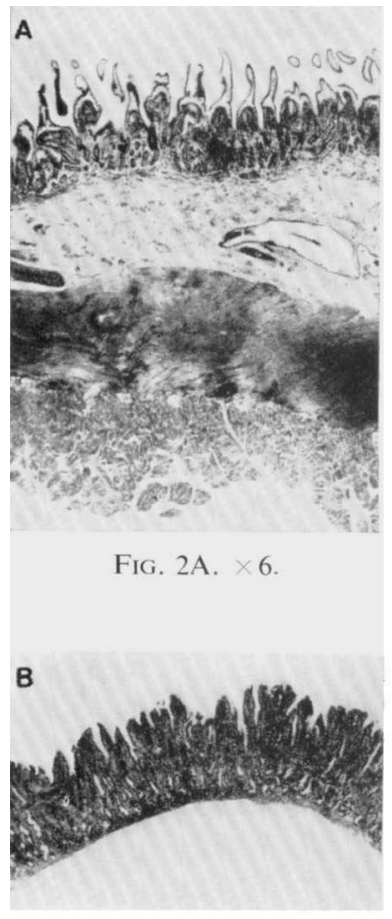

FIG. 2B. $\times 6$.

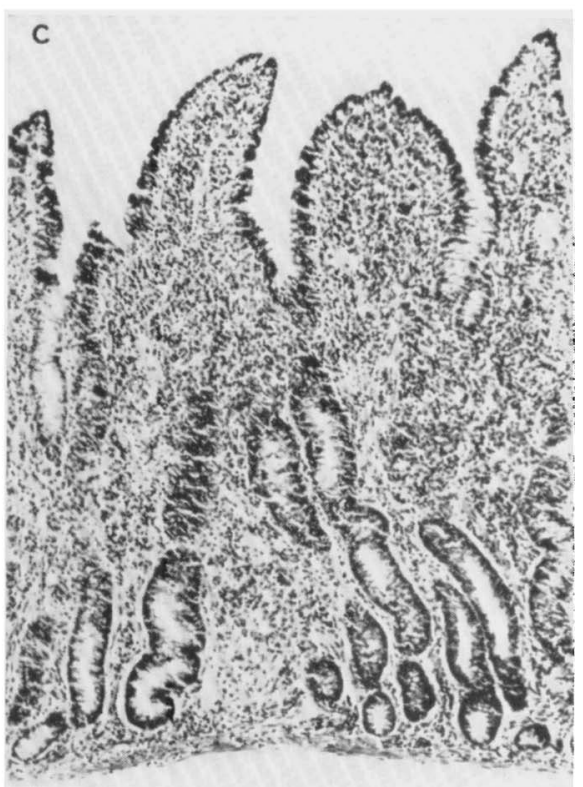

FIG. 2C. $\times 75$.

Fig. 2.-(A) Longitudinal section of normal bovine ileum. (B) Mucosal scraping from clinical case of Johne's disease, showing clean separation at level of muscularis mucosae. (C) Same scraping at higher magnification, showing retention of cellular integrity. Haematoxylin and eosin. 
Johne's disease and the proportion of "active" uptake was decreased from a normal value of about 60 per cent. to very low levels in some instances. The final concentration of L-histidine in tissue water of healthy tissues was well in excess of the concentration in the medium, and for healthy or diseased tissues the actual concentration was dependent upon the proportion of "active" uptake. The lowest levels were reached in specimens of pathological tissue. "Inactive" uptake was apparently not impaired, and it therefore appeared that diffusion across the mucosal cell membrane proceeded equally well in normal or affected tissues. The "biochemical lesion", therefore, appeared to consist of an impairment in the processes of "active " uptake. This result is of importance because malnutrition is a predictable consequence of the removal of the active transport system for amino acids (Wilson, 1962).

The intestines of animals infected with Myco. johnei have increased permeability producing abnormally large losses of plasma protein (Nielsen, 1966; Patterson et al., 1967) and the present results suggest that this is accompanied by amino-acid malabsorption. These two factors, perhaps accentuated by increased gut movement in the intermittent diarrhoeic phases of clinical Johne's disease, would tend to throw affected animals into negative nitrogen balance. Signs of a protein deficiency state including hypo-albuminaemia with a consequent shift in tissue water distribution (Patterson et al., 1968a) and wasting of the musculature (Patterson et al., 1968b) would then develop.

It is commonly found that although subclinical Myco. johnei infection may last for several years, clinical disease is suddenly precipitated by an unknown factor believed by some to be the "stress" associated with calving, change of diet and environment or other strains on the animal's metabolism. If such suggestions are valid it is possible that under "stress", protein leakage from the gut and amino-acid malabsorption might become critically important and initiate the progression from the subclinical to the clinical state. The fact that histidine uptake was found to be seriously impaired in two subclinically affected cows suggests the pre-existence of a malabsorption state.

The present findings suggest that the abnormality in amino-acid absorption in Johne's disease lies in the processes of " active " uptake by the mucosa, but there is no evidence as to precisely what metabolic pathways are interfered with. If a comparison with the metabolic effects of Myco. tuberculosis infection is permissible, it is possible that there may be a defect in the electron transport chain (cf. Kato, 1966a and $b$ ). This would almost certainly affect the energy status of the mucosal cell and decrease its capacity for "active" absorption. As it is known that there is close coupling between sodium, amino-acid and hexose transport systems in the intestinal mucosa (Parsons, 1967), the observed decrease in histidine uptake by the isolated ileum of cows affected with Johne's disease may have wider implications.

\section{SUMMARY}

Rings of whole ileum or mucosal scrapings from clinical cases of Johne's disease, or from subclinically infected animals, accumulate L-histidine at considerably less than the normal rate when incubated in Krebs-Ringer bicarbonate 
solution containing this amino acid at a concentration of $20 \mathrm{mM}$. "Active" uptake of histidine against a concentration gradient can be abolished by the addition of $0.2 \mathrm{~mm}$-2:4-dinitrophenol to the incubation medium. The proportion actively accumulated was about 61 per cent. in normal mucosal scrapings, but only some 25 per cent. in specimens obtained from clinically affected cattle.

In the same tissue preparations, the mean total rate of histidine accumulation was almost halved, but its passive uptake was virtually unaffected, indicating that, in infected cattle, histidine probably diffused into the mucosal cells normally. By direct microscopic measurement, it was found that the thickness of the mucosal tissue layer in the ileum was not significantly greater in clinically affected cattle than in healthy controls. The weight of ileum per unit length, however, was, on the average, increased almost four times on account of massive submucosal infiltration.

It is suggested that the marked reduction in the " active " uptake of histidine by the mucosa from infected animals is indicative of a malabsorption state. The part this factor plays in the pathogenesis of the terminal clinical phase of Johne's disease is discussed.

Messrs W. M. Allen and P. Anderson kindly carried out the post-mortem examinations of animals used in this study, and the assistance given by Miss C. N. Hebert, Mr M. Carwardine and Mr R. Sayer is also gratefully acknowledged.

\section{REFERENCES}

Agar, W. T., Hird, F. J. R., AND SidHu, 1954. Biochim. biophys. Acta, 14, 80. G. S.

BronK, J. R., AND PARsons, D. S. Crane, R. K., and Mandelstam, P. HUANG, K. C. . . . . . . . . . . Jubb, K. V. F., AND KenNedy, P. C.

Kato, M. ,

LEVIN, R. J. .

MacPherson, H. T.

NewEY, H., AND SMYTH, D. H.

NiELSEN, K. .

PARSONS, D. S.

Patterson, D. S. P., Allen, W. M. AND LLOYD, M. K.

Patterson, D. S. P., Allen, W. M., Berrett, Sylvia, IVINS, L. N., AND SWEASEY, D.

Patterson, D. S. P., Allen, W. M., Berrett, Sylvia, Sweasey, D., and Slater, T. F.

Patterson, D. S. P., and Berrett, 1968. Vet. Rec., 83, 55. SYLVIA

WILSON, T. H.
1965. J. Physiol., Lond., 179, 323.

1960. Biochim. biophys. Acta, 45, 460.

1965. Life Sci., 4, 1201.

1963. Pathology of domestic animals, London, vol. 2, pp. 121-122.

1966a. Amer. Rev. Resp. Dis., 93, 411.

1966b. Ibid., 93, 421.

1967. Br. Med. Bull., 23, 209.

1946. Biochem. J., 40, 470.

1967. Proc. Nutr. Soc., 26, 5.

1966. Gastro-intestinal protein loss in cattle: a clinical and pathophysiological study, Copenhagen.

1967. Proc. Nutr. Soc., 26, 46.

1967. Vet. Rec., 81, 717.

1968a. Res. Vet. Sci., 9, 117.

1968b. J. Med. Microbiol., 1, 127.

1962. Intestinal absorption, Philadelphia. 